\title{
Postscript: Visions of Love in Urban Schooling, or A Love Letter from the Editors
}

\author{
Esther O. Ohito ${ }^{1} \cdot$ Wanda Watson $^{2} \cdot$ Jamila Lyiscott $^{3} \cdot$ Yolanda Sealey-Ruiz $^{4}$
}

Published online: 13 February 2019

(c) Springer Nature B.V. 2019

\begin{abstract}
In this postscript to the special issue on love and urban schooling, the guest editors reflect on the golden thread that ties together the manuscripts included. Taken in tandem, the manuscripts in this issue question what knowledges about love have to do with urban schooling pedagogically, historically, and in the current socio-political climate while surfacing visions - that is, theories and enactments - of love by robustly interrogating this affect's meaning(s), (ab)uses, and utility in the context of urban schooling.
\end{abstract}

What's love got to do, got to do with it

What's love but a second hand emotion

What's love got to do, got to do with it

Who needs a heart when a heart can be broken

—Tina Turner (lyrics by Terence Britten and Graham Lyle), 1983

Dear Reader,

In this special themed issue of The Urban Review, we have presented articles that question what knowledges about love have to do with urban schooling pedagogically, historically, and in the current socio-political climate. This special issue has surfaced visions - that is, theories and enactments — of love in urban schooling, and interrogated love's meaning(s), (ab)uses, and utility in that context.

When conceptualizing this issue, we began with a resistance to the hegemonic understanding that "[u]rban...is a generalization as much about geography as it is about the idea that urban centers have problems: problems of too many people, too much poverty, too much crime and violence, and ultimately, too little hope"

Esther O. Ohito

ohitoe@denison.edu

1 Denison University, Granville, USA

2 Mills College, Oakland, USA

3 University of Massachusetts - Amherst, Amherst, USA

4 Teachers College, Columbia University, New York City, USA 
(Noblit and Pink 2007, p. xv). The negative connotations associated with the term "urban" contribute to too much deficit dialogue and too much problematic thinking about urban schools, communities, and community members dominating education research. As such, rarely is it that the term urban is associated with the word "love." Even more pointedly, it is rare for the word love to connote positive association with teaching, children, and urban schools, much less the teaching of children in urban schools. Those of us who use the term love in word and deed often have a deep understanding of society's disdain for those children - typically, Black, Brown, and/ or poor children-who are restricted from an opportunity to experience the fullness of education, one that may lay the foundation of promise during the foundational years of schooling. Collectively, the contributors to this issue have centered those children-as well as their teachers and their teachers teachers-when asking how scholarly attention to love, as noun and/or verb, might advance research and practice with regard to the nuanced nature of urban schooling.

\section{What's Love Got to Do with It}

The articles presented in this issue have revealed how researchers and practitioners theorize, and/or enact love with regard to "it"- the "it" here being urban schooling. Using a range of frameworks and methodological approaches, the issue's empirical and conceptual papers have pushed past sentimentalized visions of love, and, quite lovingly and rigorously, investigated the complexities of urban schooling as juxtaposed against this affect.

Urban education is the site of analysis for Boveda and Bhattacharya, who invoke their mothers' love(s) in their interrogation of love-based approaches to de/coloniality. Similarly, Caraballo and Soleimany ask what counts as love in urban educational spaces and center their investigation on a politic and "ethic of care that extends from the primary grades though higher education." Johnson, Bryan, and Boutte focus their query on the (im)possibility of loving blackness and Black lives without condition or constraint. The authors put forth theorizing that positions "a pedagogy of love as an embodied practice that influences holistic teaching." McArthur and Lane cater to Black girls when speaking to themes identifiable in the works of both Caraballo and Soleimany and Johnson, Bryan, and Boutte. Specifically, the authors "focus on love as a central tenet of authentically caring and healing pedagogies." The authors also sound the call "for Black feminism to become more reflexive, asking new and sometimes difficult questions that aim to push the theory forward." Black feminist theorizing of love is an anchor for Ohito, who inquires into the role that pleasure plays while the painful work of critical pedagogy is performed in the context of urban teacher education. Like Ohito, Cariaga relies on portraiture as methodology with which to make visible and vivid the ridges of a pedagogue's and a pedagogical journey toward the reclamation of an unconditional love. The desire to "express love through our critique of education" is what propels Reyes, Radina, and Aronson, who detail their "work together to resist Eurocentric masculinist and capitalist structures to open up transformative possibilities in education." In this very vein, Robinson-Morris remarks on what resides at the core of this special issue, asking, 
succinctly and straightforwardly: with regard to education, "what is this love, this great impossible possibility?" The author then forwards "non-Western onto-epistemological understanding(s) of subjectivity-through the South African notion of Ubuntu... and the Buddhist notion of interbeing" to question the love-based "relational aspects of the educative environment."

\section{Who Needs a Heart When a Heart Can Be Broken}

A number of the scholars featured in this issue have illustrated how-with regard to urban schooling - teaching, learning, and classrooms produce possibilities for pain (McKittrick and Hudson 2014, p. 238). Pain, however, is concomitant with love; both are affective and (inter)embodied. Love forces reckoning with changing and being changed. As Berlant (quoted in Davis and Sarlin 2011) states, "I often talk about love as one of the few places where people actually admit they want to become different...It's change without guarantees, without knowing what the other side of it is, because it's entering into relationality" (p. 8). It is this risky intensity, or the risk and possible reward of opening to this intensity, that provoked us to envision this special issue, and that we hope, dear reader, provokes your mind and your heart.

With all our love,

Esther, Wanda, Jamila, and Yolanda

\section{References}

Britten, T., \& Lyle, G. (1983). What's love got to do with it? [Recorded by T. Turner]. On Private dancer. [Cassette]. Los Angeles, CA: Capitol Records.

Davis, H., \& Sarlin, P. (2011). "On the risk of a new relationality": An interview with Lauren Berlant and Michael Hardt. Reviews in Cultural Theory, 2(3), 6-27.

Hudson, P. J. (2014). The geographies of blackness and anti-blackness: An interview with Katherine McKittrick. The CLR James Journal, 20, 233-240.

Noblit, G., \& Pink, W. (2007). Urban education in the globalizing world. In W. T. Pink \& G. W. Noblit (Eds.), International handbook of urban education (pp. xv-xxxvi). Dordrecht: Springer. 